\title{
Impact of Environmental Factors on the Carbon Dynamics at Hooghly Estuarine Region
}

\author{
Joyita Mukherjee, ${ }^{1}$ Moitreyee Banerjee, ${ }^{1}$ Arnab Banerjee, ${ }^{1}$ \\ Madhumita Roy, ${ }^{1}$ Phani Bhusan Ghosh, ${ }^{2}$ and Santanu Ray ${ }^{1}$ \\ ${ }^{1}$ Ecological Modelling Laboratory, Department of Zoology, Visva-Bharati University, Santiniketan 731235, India \\ ${ }^{2}$ Institute of Engineering and Management, Y-12, Sector-V, Salt Lake City, Kolkata 700 091, India \\ Correspondence should be addressed to Santanu Ray; sray@visva-bharati.ac.in
}

Received 30 May 2014; Revised 23 July 2014; Accepted 19 August 2014; Published 11 September 2014

Academic Editor: Winn-Jung Huang

Copyright (C) 2014 Joyita Mukherjee et al. This is an open access article distributed under the Creative Commons Attribution License, which permits unrestricted use, distribution, and reproduction in any medium, provided the original work is properly cited.

\begin{abstract}
Degradation of litter from mangrove forests adjacent to the creeks at Sagar Island of the Hooghly-Matla estuarine ecosystem is one of the principal sources of nutrient to the estuary. This system receives a major load of carbon from adjacent mangrove forest in the form of litterfall throughout the year. Keeping in view, the effect of environmental factor on the dynamics of carbon is studied through multivariate statistics. Essential environmental variables like soil carbon, dissolved carbon, temperature, salinity, $\mathrm{pH}$, and dissolved oxygen are analyzed following standard protocol. Multivariate statistical analyses like correlation, regression, and centered PCA ordination are done in order to know the impact of environmental variables on carbon dynamics. The results reflect a close intercorrelation among the studied environmental variables and carbon. It also emphasizes the fact that soil and water temperature, and dissolved oxygen affect soil carbon dynamics, whereas salinity and $\mathrm{pH}$ of soil and water greatly regulate dissolved carbon dynamics. The variance pattern of these studied variables through seasons is also enumerated by PCA ordination studies.
\end{abstract}

\section{Introduction}

Out of the fourteen major rivers, the Ganges $(2,525 \mathrm{~km}$ in length) along with its tributaries is the largest major river basin in India $[1,2]$. It originates in the Gangotri glacier in the Himalayas in the state of Uttarakhand and its first deltaic offshoot is known as Hooghly estuary $\left(21^{\circ} 31^{\prime}-23^{\circ} 20^{\prime} \mathrm{N}\right.$ and $\left.87^{\circ} 45^{\prime}-88^{\circ} 45^{\prime} \mathrm{E}\right)$. Sundarbans, vast lush green mangroves with distinctive faunal diversity, is located along the coastal line of Bay of Bengal, where the Ganges meets the sea (Figure 1). A wide variety of fishes harbour in the whole estuarine area and so the livelihood of the local people is mainly dependent on this ecosystem.

Construction of barrage at Farakka, port activity, dredging, and discharge of sewage hamper the normal activity of the estuary [3]. Primary production is controlled by the light availability that depends on the concentration of suspended particulate matter [4] and surface water remains undersaturated with respect to dissolved oxygen and production of large quantities of dissolved carbon dioxide also takes place in this estuary [5]. This estuary seems to be net heterotrophic ecosystem and the order of magnitude of the resulting atmospheric $\mathrm{CO}_{2}$ source has also been studied. Diurnal and seasonal variations, seasonal effects, and driving forces behind air water $\mathrm{CO}_{2}$ exchange are investigated $[6,7]$. The atmospheric profile of $\mathrm{CO}_{2}$ and $\mathrm{CH}_{4}$ from Sundarban mangrove biosphere which is an important database for greenhouse gas emission from such coastal wetlands is studied [6]. Large amounts of materials, such as nutrient, silt, clay, and suspended particulate matter, are transported through this estuary following heavy rains during monsoon period. Addition of organic matter in the form of litter $\left(1603 \mathrm{~g} \mathrm{~m}^{-2}\right.$ year $\left.^{-1}\right)[8]$ from the Sundarban mangrove forest at the land-ocean boundary is also expected throughout the year. This extent of input of organic matter might have considerable effect on the metabolic function of the system as well as having several fold increase of nutrient transport. Annual mass balance for $\mathrm{C}, \mathrm{N}, \mathrm{P}$, and $\mathrm{Si}$ in the Gangetic delta was also estimated [9]. Mandal et al. [10] studied the mangrove litter degradation of a reclaimed island of 
this estuary and quantified different forms of nitrogen in soil and water and different environmental factors. A dynamic model was also worked out with respect to the contribution of dissolved inorganic nitrogen (DIN) from litterfall of adjacent mangrove forest to Hooghly-Matla estuary [10]. Phytoplankton composition and abundance are important when estimating the primary production of this estuary. Key phytoplankton species, their seasonal fluctuation and bloom, and environmental factors regulating their abundance are studied $[3,11]$. The most important forms of inorganic carbon in estuary are dissolved inorganic carbon (DIC), dissolved carbon dioxide $\left(\mathrm{DCO}_{2}\right)$, and dissolved bicarbonate (DBC). The organic pools include dissolved organic carbon (DOC) and particulate organic carbon (POC) [12].

The aim of the present study is to quantify the amount of different forms of carbon present in soil and water of the estuary and how the dynamics of different forms of carbon is regulated by the physical factors in this estuary. For this purpose seven different forms of carbon, namely, soil inorganic carbon (SIC), soil organic carbon (SOC), dissolved inorganic carbon of water (DIC), dissolved carbon dioxide of water $\left(\mathrm{DCO}_{2}\right)$, dissolved bicarbonate of water (DBC), dissolved organic carbon of water (DOC), and particulate organic carbon of water (POC), are taken into consideration. The objective of the present study is the assessment of the importance of different environmental factors and their role in carbon dynamics through statistical analyses.

\section{Materials and Methods}

2.1. Study Site. Sundarbans is the mangrove dominated delta of the Ganges and is one of the best-known detritus-based ecosystems of the world [13]. The Sundarbans in India has total area of $3682.76 \mathrm{~km}^{2}$ including 110 deltaic islands of which 54 have been reclaimed by human population in earlier periods and remaining 56 are marked for reserved forests including the tiger reserve $[14,15]$. The area is located between $21^{\circ} 10^{\prime} \mathrm{E}$ and $22^{\circ} 30^{\prime} \mathrm{E}$ latitude and $88^{\circ} 15^{\prime} \mathrm{N}$ and $89^{\circ} 40^{\prime} \mathrm{N}$ longitude. An enormous amount of sediment is delivered by the Ganges into the Bay of Bengal through the drainage of the southern slopes of the Himalayas. A tributary of this river, the Hooghly, is the main artery of Sundarban mangrove ecosystem and is mainly dominated by fresh water discharge from the Farakka dam situated $286 \mathrm{~km}$ upstream from the mouth. Semidiurnal tides are observed in this area with mesomacrotidal amplitude, that is, 2.5-7.0 m, with mean current velocities of 117 and $108 \mathrm{~cm} \mathrm{~s}^{-1}$, respectively, during high and low tides [11]. The physiographic features include deltaic formations with numerous drainage lines associated with surface and subaqueous levees, splays, and tidal flats. Marginal marshes are also present above the mean tide level, tidal sandbars, and islands along with networks of tidal channels, subaqueous distal bars, and protodelta clay and silt sediments. The area can be roughly divided into four geomorphologic classes like alluvial, mixed or transitional, coastal, and marine [16].

The present study has been done in Sagar Island, the largest island in the deltaic offshoot of the Ganges.

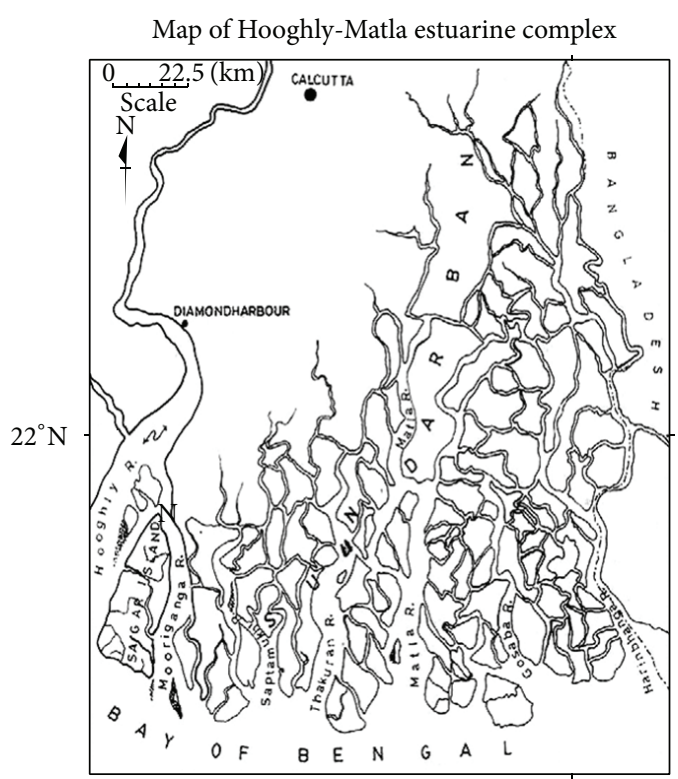

$89^{\circ} \mathrm{E}$

FIGURE 1: Map of Hooghly estuary showing study site, Sagar Island.

The Sundarbans, a unique bioclimatic zone, is expanded over the borders of two countries, India and Bangladesh, $8048.46 \mathrm{~km}^{2}$ together [14]. A number of rivers, creeks, and canals crisscross the areas like a network [7, 17]. Hooghly estuary, a mesomacrotidal estuary, shows a wide mixing zone extending from Diamond Harbor to the mouth of the river [11]. Sagar Island, lying between $21^{\circ} 56^{\prime}-21^{\circ} 88^{\prime} \mathrm{N}$ and $88^{\circ} 08^{\prime}-88^{\circ} 16^{\prime} \mathrm{E}$, is located in the western sector of the estuary (Figure 1). The island is about $144.9 \mathrm{~km}^{2}$ in area and is surrounded by the river Hooghly on the north and northwest and the river Mooriganga on the east [17]. South western wind controls the monsoon here. During premonsoon when the river runoff is low, temperature and salinity remain high. With the onset of the monsoon, nutrient and suspended matters increase. This region is under the wet tropical climatic zone, with pronounced seasonal climatic changes. The seasons can be divided into premonsoon (March-June) with average high temperature ranging from 27 to $46^{\circ} \mathrm{C}$ and minimum rainfall; monsoon (July-October), about $80 \%$ of annual rainfall occurring; and postmonsoon (NovemberFebruary), with cold weather (average $23^{\circ} \mathrm{C}$ ) and negligible rainfall. The monsoon season is generally dominated by southwest winds. The average humidity is about $80 \%$ and more or less uniform throughout the year. Avicennia marina (grey mangrove) is the dominant species among the halophytes of Sagar Island. Avicenna alba, Porteresia coarctata, Excoecaria agallocha, Ceriops decandra, Acanthus ilicifolius, and Derris trifoliate are also present [18].

2.2. Sampling and Experiments. Several experimental and survey works were done for the period over two years (January 2010-December 2011) in the study sites to collect the data of litter biomass, different forms of carbon of soil and water, soil salinity $\left(S_{s}\right)$, soil $\mathrm{pH}\left(S_{\mathrm{pH}}\right)$, soil temperature 
$\left(S_{T}\right)$, redox potential $\left(R_{p}\right)$, water temperature $\left(W_{T}\right)$, dissolved oxygen $\left(D_{\mathrm{O}}\right)$ and water $\mathrm{pH}\left(W_{\mathrm{pH}}\right)$, surface solar irradiance $\left(I_{R}\right)$, and salinity of upstream $\left(S_{r}\right)$ and downstream $\left(S_{e}\right)$ of the estuary.

Samples were collected from the substratum of mangrove forest and the creeks of Sagar Island. Field and experimental data were generated for two years from the investigated site. The data covers the dissolved and particulate organic carbon, water temperature, water $\mathrm{pH}$, dissolved oxygen, dissolved carbon dioxide, soil organic carbon, soil temperature, and salinity.

Soil samples were collected at monthly intervals from the field stations at a depth of $\sim 8-10$ inches $(\sim 20-25 \mathrm{~cm})$ from the mangrove swamps, where tidal flow is encountered. Soil temperature is measured in the field using a digital thermometer (EUROLAB-ST 9269). Soil organic and inorganic carbon contents were estimated following standard methods. Soil organic carbon was estimated by Walkley and Black method [19]. The basic principle of this method is wet oxidation of organic carbon in an acid dichromate solution followed by back titration of the remaining dichromate with ferrous ammonium sulphate solution. Carbonate and bicarbonate of the soil were determined by titrating definite amount of soil and soil water extract against standard acid using phenolphthalein and methyl orange indicators, respectively [20], and the amount of inorganic carbon was then calculated. From a saturated soil-water paste (1:10 ratio) $\mathrm{pH}$ was measured monthly [20]. Soil salinity was derived from soil water extracts following the method of Gupta [20] and calculated by the following formula: salinity $(\mathrm{ppt})=$ chlorinity $(\mathrm{ppt})$ $1.805+0.03$ [21]. Estuarine water samples were collected from the creeks at $0.5 \mathrm{~m}$ (about 20 inches approximately) depth at different field stations for chemical analysis. Samples for DOC and POC were collected in glass bottles in the field and preserved on ice in dark condition and carried to the laboratory. TOC in these samples were estimated using TOC analyzer (Shimadzu). Water samples were passed through Millipore $\mathrm{GF} / \mathrm{F}$ filters $(0.45 \mu \mathrm{m}$ pore size $)$ and the filtrate was used to determine POC. Total alkalinity (TA) of the samples was estimated by potentiometric titration [22] and calibrated against standard sea water procured from NIO (National Institute of Oceanography, India). Dissolved inorganic carbon (DIC) was measured from TA. Dissolved free carbon dioxide $\left(\mathrm{DCO}_{2}\right)$ was measured following standard titration method using sodium hydroxide titrant and phenolphthalein indicator [20]. Bicarbonate alkalinity was calculated using mathematical formulae [22]. Water temperature was measured directly from the field using digital instrument (EUROLAB-ST 9269) and dissolved oxygen was measured by Winkler's iodometric method. Water $\mathrm{pH}$ was measured using $\mathrm{pH}$ meter (LUTRON-pH-206). Digital instruments (LUTRON-LX 101, EUTECH-ECOSCAN SALT6) were used to measure irradiance and salinity of water, respectively.

Monthly data for dry litter biomass, flux of carbon dioxide at air-water interface, and community respiration were taken from the previous works of the same locality $[7,9]$.

2.3. Statistical Enumeration. Statistical analysis was done using software S-PLUS 4.0. Multiple regression squared value,
TABle 1: $P$ values for MANOVA done to show effects of seasons and year on different forms of carbon.

\begin{tabular}{lc}
\hline Independent variables & $P$ value \\
\hline Year and season & $>0.5$ \\
Year & $>0.1$ \\
Season & $<0.001$ \\
\hline
\end{tabular}

correlation matrix, and multivariate analysis of variance (MANOVA) were used to predict the relationship of considered environmental factors with different forms of carbon. Environmental characteristics are multivariate variables and thus methods of multivariate statistics relating to water quality are essential. Even techniques related to water quality analysis are based on indirect gradient analysis, also called ordination technique [23]. Each descriptor (variables) is usually calculated with a particular set of observations according to the experiment designed (in this case 24) observations. Thus characterization of the main trend of variation in these observations with respect to all descriptors is evitable [24]. To understand the interaction of all studied environmental variables which can be considered as independent variables, a reduction in the data set is necessary. Principal component analysis (PCA) is the most appropriate method for dimension reduction in space and indirect gradient analysis for improved data interpretation. PCA in this study was analyzed with SPSS 20, IBM Corp., 2011.

\section{Results}

At first, year and season are taken as two independent variables and different forms of carbon (SIC, SOC, DIC, $\mathrm{DCO}_{2}, \mathrm{DBC}, \mathrm{DOC}$, and POC) as the dependent variables for MANOVA. Result shows that year and seasons do not have any significant effect on the dependent variable (Table 1). When seasons and year are considered separately as the independent variables for MANOVA, it shows that seasons have quite significant effect on the dependent variable (Table 1) whereas year does not have any significant effect (Table 1). The reason is quite acceptable. Different environmental factors vary widely along with different seasons. But the changes in environmental factors during two consecutive years are not significant, so its effect on the dependent variables is insignificant.

Correlation analysis has been done to understand the relation among the different environmental factors and different forms of carbon (Table 2). The study reveals strong correlation among SIC and SOC with litter biomass, dissolved oxygen, and soil and water temperature. DIC, DBC, DOC, and POC are strongly correlated to soil and water salinity, soil and water $\mathrm{pH}$, and community respiration.

Correlation analysis of all studied environmental variables shows that 16 variables are highly correlated to each other, which includes all forms of carbon except dissolved $\mathrm{CO}_{2}$, soil $\mathrm{pH}\left(S_{\mathrm{pH}}\right)$, soil temperature $\left(S_{T}\right)$, soil salinity $\left(S_{S}\right)$, redox potential $\left(R_{p}\right)$, water $\mathrm{pH}\left(W_{\mathrm{pH}}\right)$, water temperature $\left(W_{T}\right)$, water salinity $\left(W_{S}\right)$, dissolved oxygen $\left(D_{\mathrm{O}}\right)$, litter biomass $\left(L_{B}\right)$, and respiration $(R)$. 
TABLE 2: Correlation among all the variables considered for the study.

\begin{tabular}{|c|c|c|c|c|c|c|c|c|c|c|c|c|c|c|c|c|}
\hline & SOC & SIC & DIC & $\mathrm{DBC}$ & DOC & POC & $S_{s}$ & $S_{\mathrm{pH}}$ & $S_{T}$ & $W_{S}$ & $W_{\mathrm{pH}}$ & $W_{T}$ & $D_{\mathrm{O}}$ & $L_{B}$ & $R$ & $R_{p}$ \\
\hline SOC & 1 & -0.927 & -0.298 & -0.296 & -0.080 & -0.524 & -0.415 & 0.580 & -0.935 & -0.389 & -0.199 & -0.958 & 0.765 & 0.863 & -0.194 & -0.198 \\
\hline SIC & -0.927 & 1 & 0.471 & 0.470 & 0.231 & 0.621 & 0.546 & -0.592 & 0.859 & 0.530 & 0.381 & 0.897 & -0.726 & 0.774 & 0.345 & 0.326 \\
\hline DIC & -0.298 & 0.471 & 1 & 0.999 & 0.851 & 0.805 & 0.805 & -0.692 & 0.143 & 0.824 & 0.730 & 0.225 & -0.029 & 0.040 & 0.969 & 0.784 \\
\hline $\mathrm{DBC}$ & -0.296 & 0.476 & 0.999 & 1 & 0.853 & 0.803 & 0.805 & -0.695 & 0.143 & 0.825 & 0.723 & 0.228 & -0.034 & 0.036 & 0.970 & 0.779 \\
\hline DOC & -0.080 & 0.231 & 0.851 & 0.853 & 1 & 0.853 & 0.884 & -0.656 & -0.093 & 0.894 & 0.703 & -0.025 & 0.264 & 0.285 & 0.923 & 0.924 \\
\hline POC & -0.524 & 0.621 & 0.805 & 0.803 & 0.853 & 1 & 0.973 & -0.823 & 0.339 & 0.963 & 0.617 & 0.398 & -0.112 & -0.115 & 0.796 & 0.914 \\
\hline$S_{s}$ & -0.415 & 0.546 & 0.805 & 0.805 & 0.884 & 0.973 & 1 & -0.746 & 0.238 & 0.994 & 0.579 & 0.314 & -0.081 & -0.026 & 0.796 & 0.907 \\
\hline$S_{\mathrm{pH}}$ & 0.580 & -0.592 & -0.692 & -0.695 & -0.656 & -0.823 & -0.746 & 1 & -0.389 & -0.771 & -0.406 & -0.493 & 0.173 & 0.282 & -0.682 & -0.699 \\
\hline$S_{T}$ & -0.935 & 0.859 & 0.143 & 0.143 & -0.093 & 0.339 & 0.238 & -0.389 & 1 & 0.192 & 0.140 & 0.960 & 0.826 & -0.858 & 0.041 & -0.036 \\
\hline$W_{S}$ & -0.389 & 0.530 & 0.824 & 0.825 & 0.894 & 0.963 & 0.994 & -0.771 & 0.192 & 1 & 0.570 & 0.286 & -0.054 & -0.012 & 0.814 & 0.916 \\
\hline$W_{\mathrm{pH}}$ & -0.199 & 0.381 & 0.730 & 0.723 & 0.703 & 0.617 & 0.579 & -0.406 & 0.140 & 0.570 & 1 & 0.109 & 0.203 & 0.155 & 0.753 & 0.676 \\
\hline$W_{T}$ & -0.958 & 0.897 & 0.225 & 0.228 & -0.025 & 0.398 & 0.314 & -0.493 & 0.960 & 0.286 & 0.109 & 1 & -0.798 & -0.897 & 0.106 & 0.032 \\
\hline$D_{\mathrm{O}}$ & 0.765 & -0.726 & -0.029 & -0.034 & 0.264 & -0.112 & -0.081 & 0.173 & 0.826 & -0.054 & 0.203 & -0.798 & 1 & 0.846 & 0.094 & 0.250 \\
\hline$L_{B}$ & 0.863 & 0.774 & 0.040 & 0.036 & 0.285 & -0.115 & -0.026 & 0.282 & -0.858 & -0.012 & 0.155 & -0.897 & 0.846 & 1 & 0.144 & 0.210 \\
\hline$R$ & -0.194 & 0.345 & 0.969 & 0.970 & 0.923 & 0.796 & 0.796 & -0.682 & 0.041 & 0.814 & 0.753 & 0.106 & 0.094 & 0.144 & 1 & 0.816 \\
\hline$R_{p}$ & -0.198 & 0.326 & 0.784 & 0.779 & 0.924 & 0.914 & 0.907 & -0.699 & -0.036 & 0.916 & 0.676 & 0.032 & 0.250 & 0.210 & 0.816 & 1 \\
\hline
\end{tabular}

TABLE 3: Correlation among different environmental factors with SOC and SIC.

\begin{tabular}{lcccc}
\hline & $L_{B}$ & $S_{T}$ & $S_{\mathrm{pH}}$ & $D_{\mathrm{O}}$ \\
\hline SOC & 0.863 & -0.935 & 0.580 & 0.765 \\
SIC & -0.774 & 0.859 & 0.592 & -0.726 \\
\hline
\end{tabular}

Correlation between environmental variables and different soil carbon forms reveals that soil organic carbon has significant correlation to litter biomass, soil and water temperature, and dissolved oxygen. Soil inorganic carbon also shows significant correlation with litter biomass, soil temperature, water temperature, and dissolved oxygen (Table 3).

Correlation analysis among different environmental factors with different forms of carbon present in water shows that all forms of carbon, that is, DIC, DOC, DBC, and POC,are highly correlated to salinity and $\mathrm{pH}$ for both soil and water along with community respiration and redox potential (Table 4).

The environmental factors which show high correlation coefficient value with respect to SOC, SIC, DIC, DBC, DOC, and POC are considered for regression analysis (Figures 2 and 3).

Centered PCA ordination of environmental variables for the study periods 2010 and 2011 revealed more or less similar trajectories in a PCA biplot (Figures 4(a) and 4(b)). In both years total variance explained for the said variables accounts for $86.45 \%$ and $84.82 \%$ for the years 2010 and 2011, respectively. The rotated component matrix following Varimax method with Kaiser Normalisation also projected the same component extraction for the study period (Tables 5 and 6).

Rotated component matrix shows that maximum variance is contributed by 10 variables which include all forms of carbon in water, along with $\mathrm{pH}$ and salinity of soil and water, community respiration, and redox potential. The rest of the variables contribute a similar variance pattern which includes both forms of soil carbon, soil and water temperature, dissolved oxygen, and litter biomass.

A PCA biplot (Figure 5) is made to analyze the variation pattern of the studied variables through seasons. It revealed that maximum variation was recorded in the months of March, April, June, and February. The late monsoon and winter months are stable in relation to environmental variable. Data reduction through PCA was successfully done in the present study for the years 2010 and 2011.

\section{Discussion}

Mangrove wetlands along tropical estuaries are considered as intertidal community and ecotones of marine to fresh water ecosystems [25]. Inputs from terrestrial runoff generally are considered the major nutrient source that supports mangrove forest development [26-28]. Large differences in $\mathrm{pH}, \mathrm{DIC}$, and alkalinity in rivers demonstrate the differences of material inputs to the rivers. Drastic change in $\mathrm{pH}$ at the mixing zone of rivers, especially for the coastal plain rivers, causes lower buffering capacity of river in spite of their high humic matter content [29]. In this work it has been found that salinity, rainfall, and respiration of the biotic community have influence on the water profile of Sundarban mangrove ecosystem. Studies also suggest that the most probable causes that uphold the high $\mathrm{pCO}_{2}$ values and high water-to-air fluxes of $\mathrm{CO}_{2}$ in the estuary are inputs from organic carbon respiration in the tidally flooded salt marshes and groundwater.

The central idea of principal component analysis (PCA) is to reduce the dimensionality of a data set consisting of a large number of interrelated variables, while retaining as much as possible of the variation present in the data set [30]. It has clearly reduced the entire data set into two principal components completely partitioning the variables based on their similar variance pattern and also accounted 


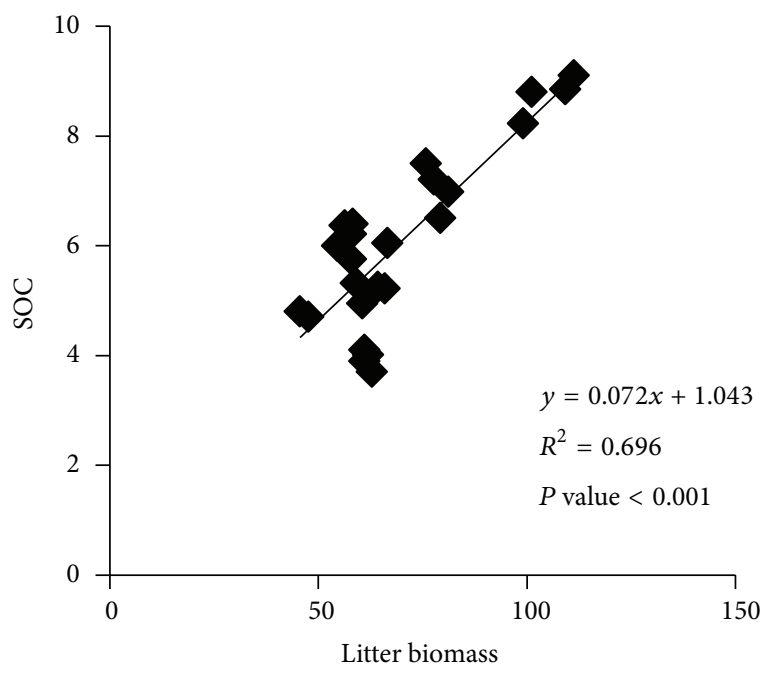

(a)

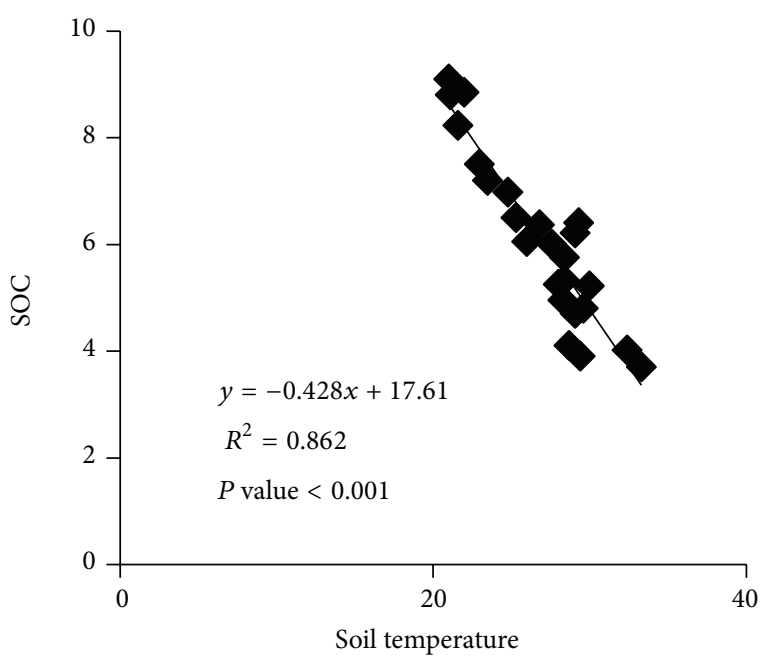

(c)

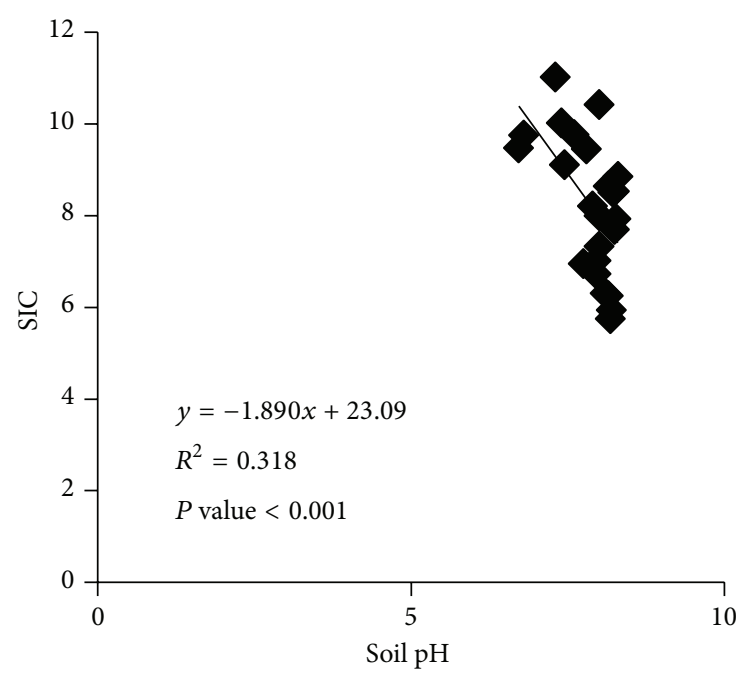

(e)

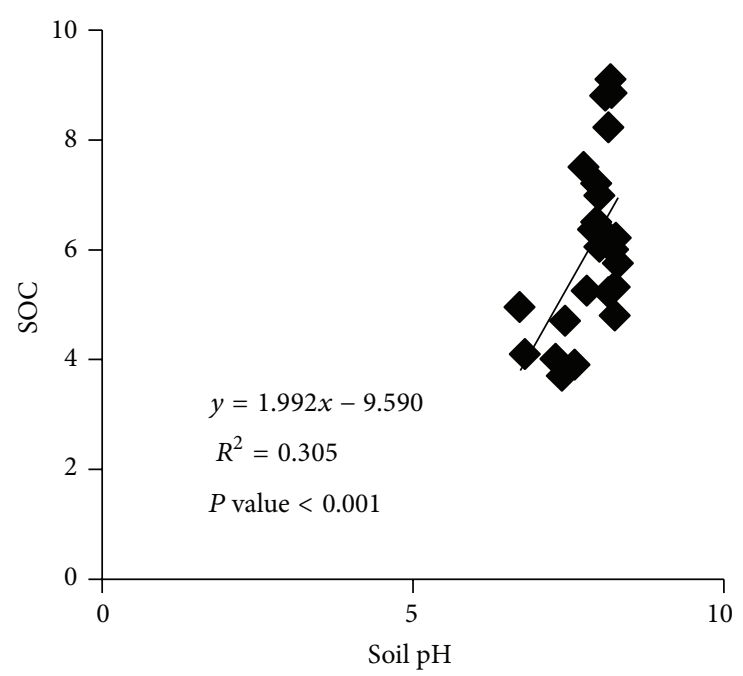

(b)

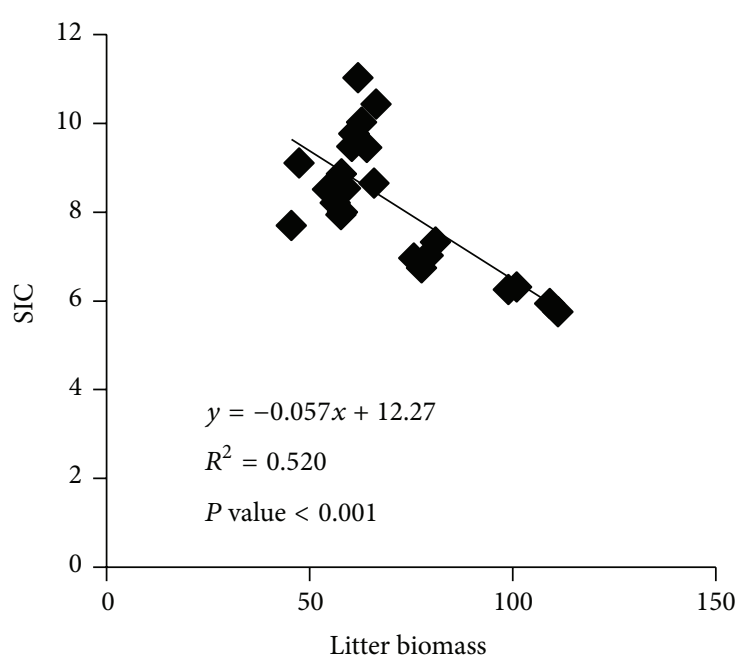

(d)

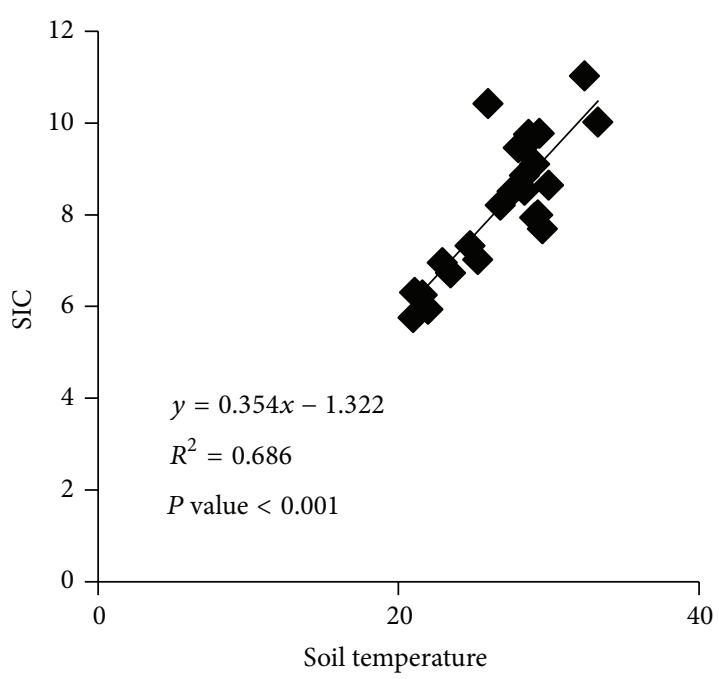

(f)

FIGURE 2: All graphs are showing regression lines and $P$ values obtained from regression analysis results of (a) litter biomass and SOC; (b) soil $\mathrm{pH}$ and SOC; (c) soil temperature and SOC; (d) litter biomass and SIC; (e) soil pH and SIC; and (f) soil temperature and SIC. 


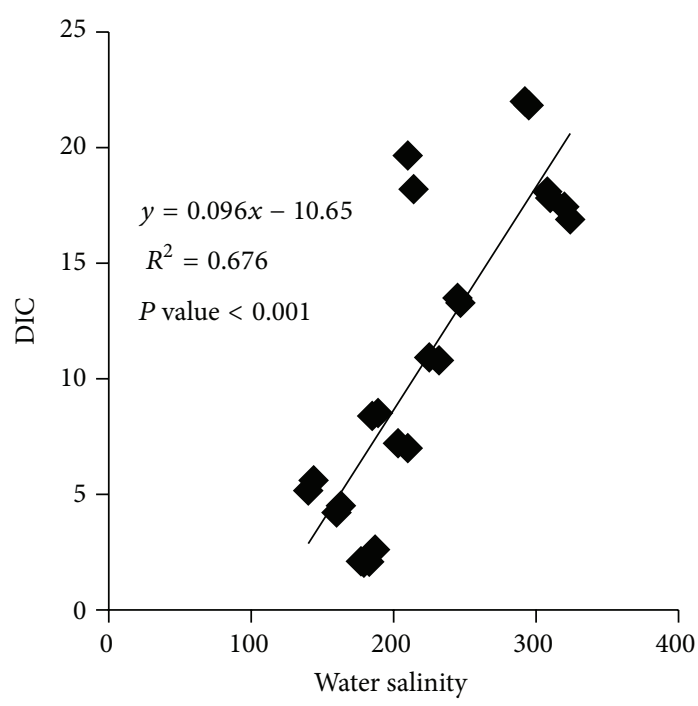

(a)

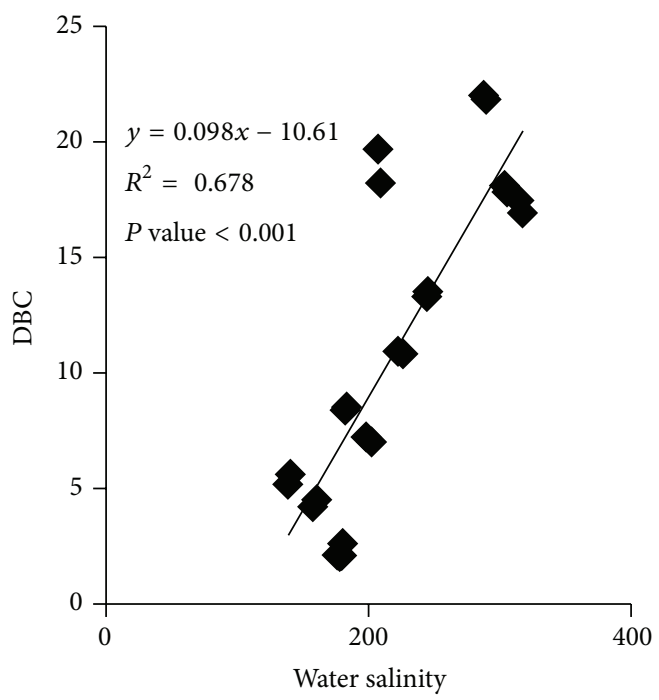

(c)

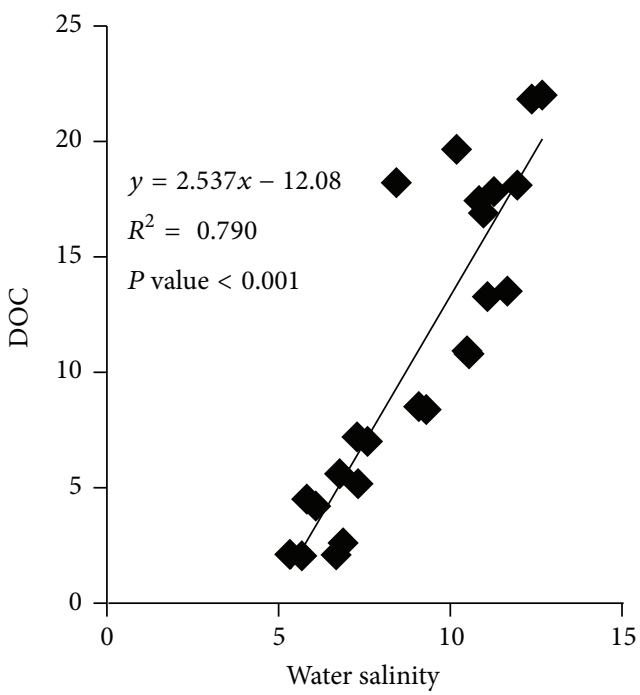

(e)

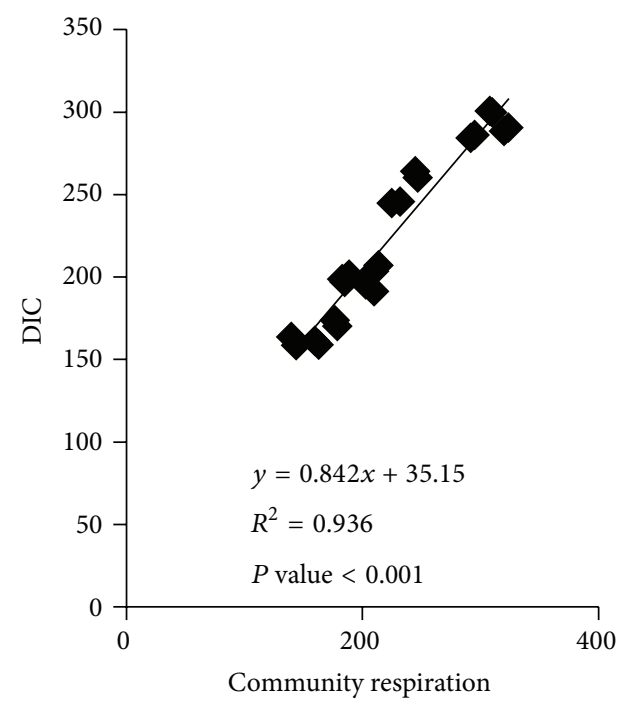

(b)

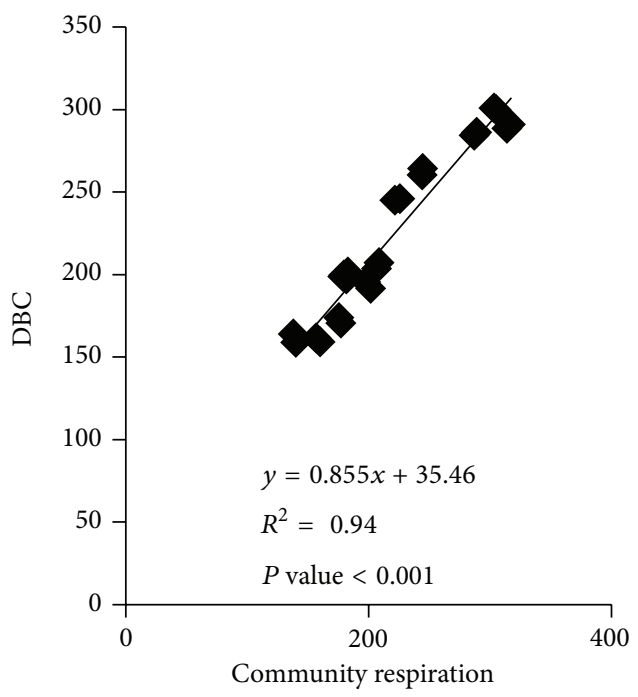

(d)

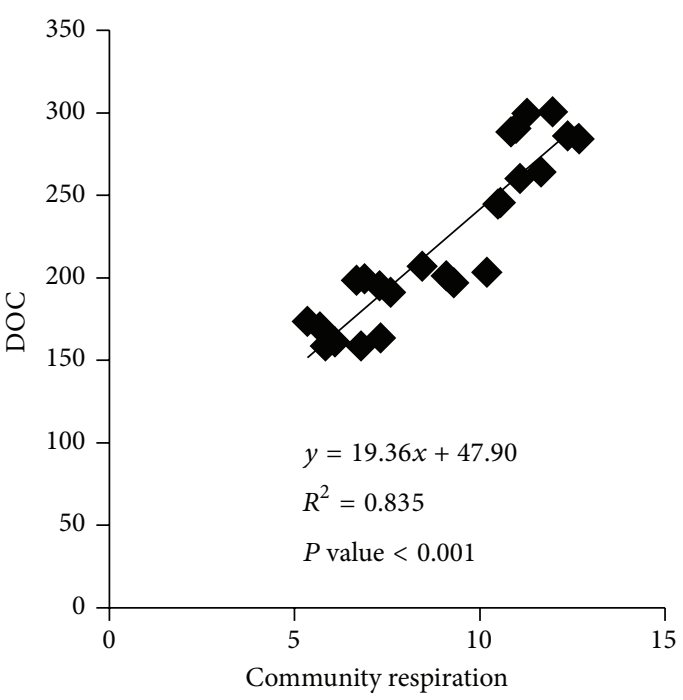

(f)

Figure 3: Continued. 


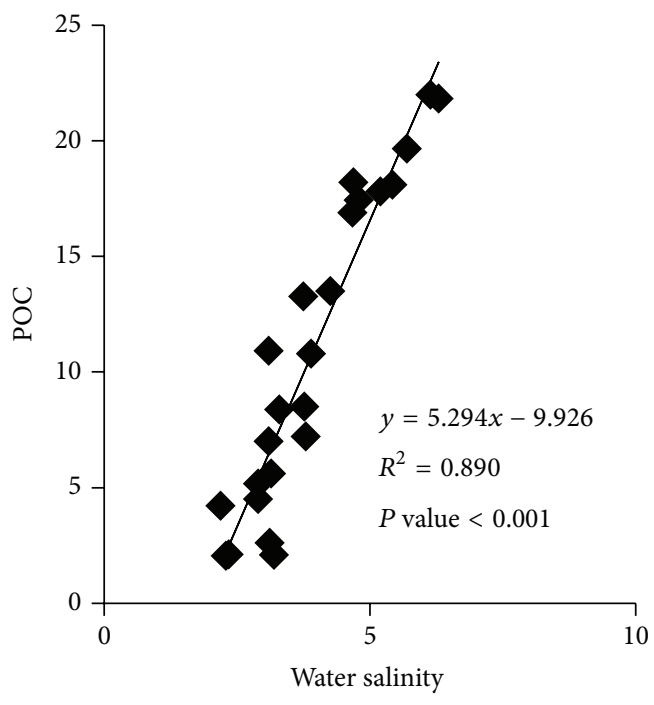

(g)

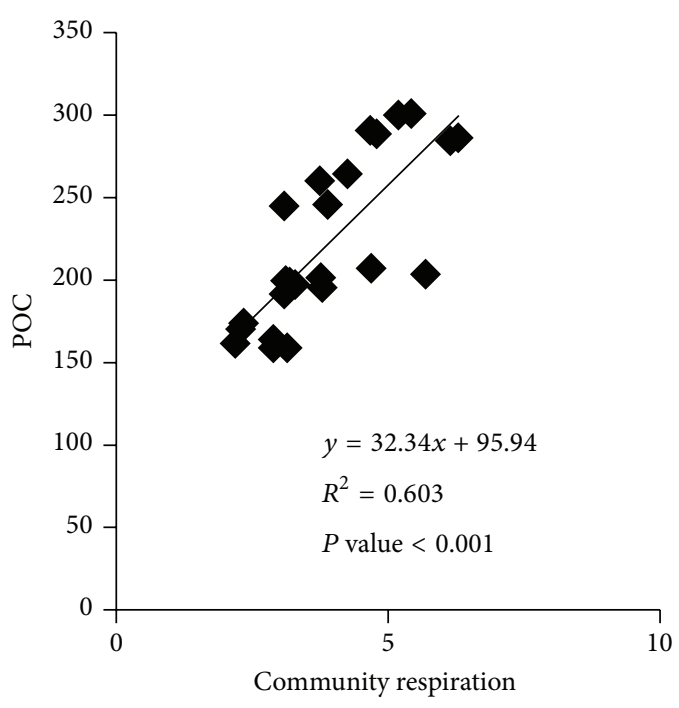

(h)

FIGURE 3: All graphs are showing regression lines and $P$ values obtained from regression analysis results of (a) water salinity and DIC; (b) community respiration and DIC; (c) water salinity and DBC; (d) community respiration and DBC; (e) water salinity and DOC; (f) community respiration and DOC; (g) water salinity and POC; and (h) community respiration and POC.

Component plot in rotated space

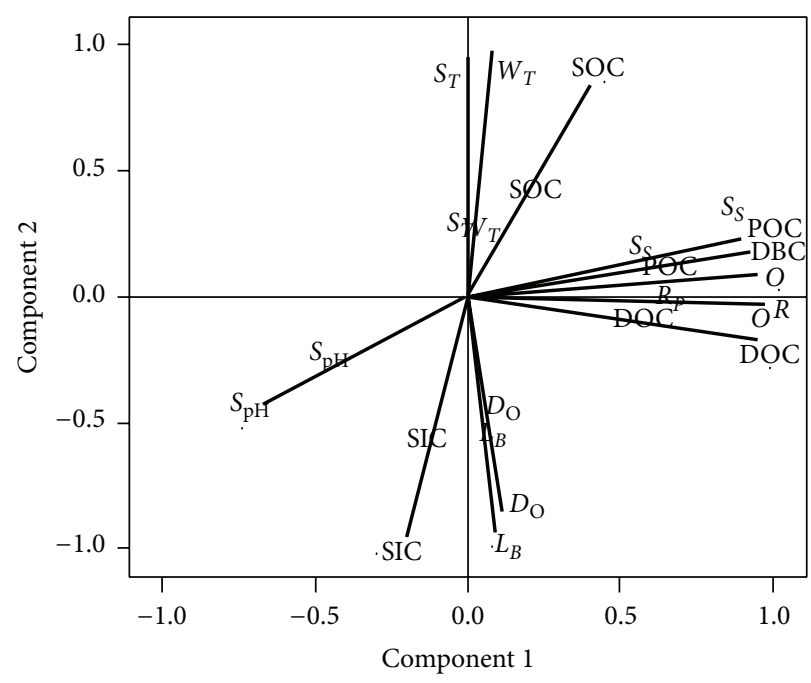

(a)
Component plot in rotated space

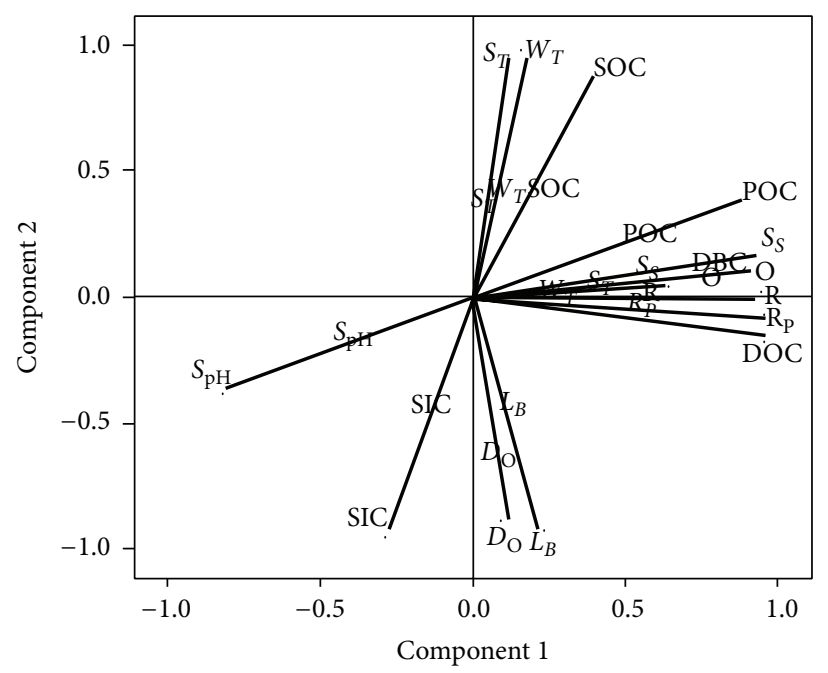

(b)

Figure 4: (a) PCA biplot for the year 2010. (b) PCA biplot for the year 2011.

TABLE 4: Correlation among different environmental factors with DIC, DBC, DOC, and POC.

\begin{tabular}{lcccc}
\hline & DIC & DBC & DOC & POC \\
\hline$S_{s}$ & 0.805 & 0.805 & 0.884 & 0.973 \\
$S_{\mathrm{pH}}$ & -0.692 & -0.695 & -0.656 & -0.823 \\
$W_{S}$ & 0.824 & 0.825 & 0.894 & 0.963 \\
$W_{\mathrm{pH}}$ & 0.730 & 0.723 & 0.703 & 0.617 \\
$R$ & 0.969 & 0.970 & 0.923 & 0.796 \\
$R_{p}$ & 0.784 & 0.779 & 0.924 & 0.914 \\
\hline
\end{tabular}




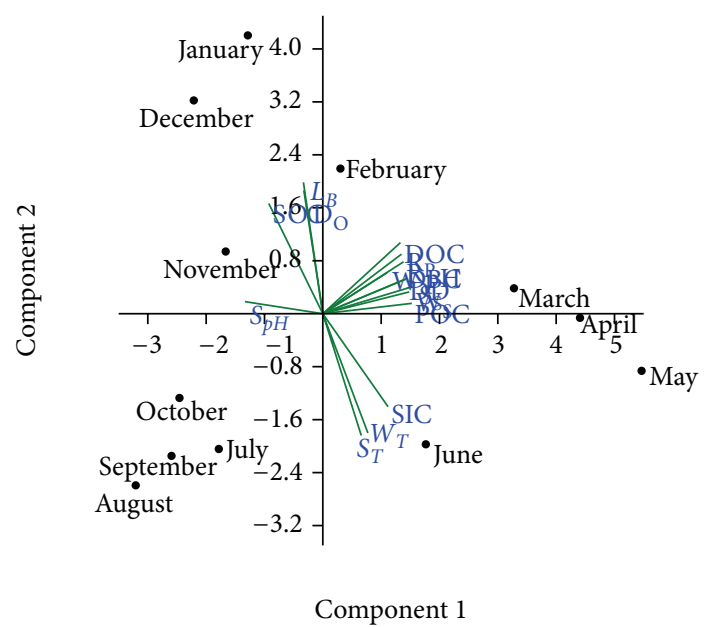

FIGURE 5: PCA biplot showing the components using pooled data for 24 months.

TABLE 5: Rotation with Varimax method, Kaiser Normalisation (2010).

\begin{tabular}{lcc}
\hline & \multicolumn{2}{c}{ Component } \\
\hline SIC & 1 & 2 \\
SOC & & -0.937 \\
DIC & 0.911 & 0.878 \\
DBC & 0.911 & \\
DOC & 0.962 & \\
POC & 0.885 & \\
$S_{s}$ & 0.935 & \\
$S_{\mathrm{pH}}$ & -0.808 & \\
$S_{T}$ & & \\
$W_{S}$ & 0.943 & \\
$W_{\mathrm{pH}}$ & 0.634 & \\
$W_{T}$ & & -0.953 \\
$D_{\mathrm{O}}$ & & \\
$L_{B}$ & & \\
$R$ & 0.927 & \\
$R_{p}$ & 0.964 & \\
\hline
\end{tabular}

for more than $80 \%$ of total variance explained during PCA. The PCA biplot (Figure 5) showed that March and April, the premonsoon months, experienced maximum variation in all forms of carbon dissolved in water along with salinity of soil and water, soil and water $\mathrm{pH}$, redox potential, and community respiration. The month of monsoon experienced variation in soil inorganic carbon along with temperature of soil and water. Litter biomass, soil organic carbon, and dissolved oxygen varied greatly in February and November.

It is seen in the present study, during summer, that microbial activity is increased due to a high temperature leading to increased rate of mineralization. SIC shows higher value in summer months. All the forms of carbon are transformed from one to another and the process of interconversion is highly dependent on environmental factors
TABLE 6: Rotation with Varimax method, Kaiser Normalisation (2011).

\begin{tabular}{lcc}
\hline & \multicolumn{2}{c}{ Component } \\
\hline SIC & 1 & 2 \\
SOC & & -0.960 \\
DIC & 0.952 & 0.855 \\
DBC & 0.952 & \\
DOC & 0.966 & \\
POC & 0.933 & \\
$S_{s}$ & 0.902 & \\
$S_{\mathrm{pH}}$ & -0.676 & \\
$S_{T}$ & & \\
$W_{S}$ & 0.920 & \\
$W_{\mathrm{pH}}$ & & -0.974 \\
$W_{T}$ & & -0.943 \\
$D_{\mathrm{O}}$ & & \\
$L_{B}$ & & \\
$R$ & 0.971 & \\
$R_{p}$ & 0.971 &
\end{tabular}

in this estuary [31]. Complex gradients of hydroperiod and soil conditions such as nutrient limitation (e.g., nitrogen and phosphorus content) control the pattern of mangrove forest patches [32, 33]. Abiotic stress factors (e.g., salinity and sulphide) can also lead to heterogeneous community structure of mangroves [34-38]. During premonsoon, water and soil temperature gradually increase. It is seen in different regions that nutrient availability in mangrove soils decreases from the landward zone to the seaward zone along the estuarine gradient of tropical estuary. Tidal inundation has a large effect on the species habitat zonation in the mangrove areas $[39,40]$. In the monsoon months due to rain and water runoff, water logging condition often prevails in the adjoining mangrove forest substratum of estuary and prevents the penetration of atmospheric oxygen lowering the activity of bacteria and fungi and other detritivores present in the soil. Thus the value of SIC remains low in monsoon. Community respiration also remains high in these months. Just after the winter, community metabolism raises which results in high respiration and subsequent rise in DIC value. DBC is a part of DIC pool; thus an increase in DICboosts the level of DBCin water. As DIC of water reaches maximum it has effect upon the $\mathrm{pH}$ of water. Salinity also remains very high at that time. Alkalinity and dissolved inorganic carbon (DIC) show conservative behaviour in this estuary like most of the other estuaries (e.g., Columbia River and upper Chesapeake Bay) [41, 42]. Salinity is an important environmental factor determining mangrove growth [28]. In the Hooghly estuary salinity does not show any linear correlation with DIC, alkalinity. This kind of result is also supported by study on USA rivers like Shark river estuary. Salinity regime of the river at different regions shows significant difference at sites and also between years depending on freshwater inflow. But the salinity change does not follow any linear relationship 
with nutrient condition of the river or other environmental variables [28].

Characteristics of mangroves change with its environmental status which depends on its location, salinity gradient of an estuary, and distance from the shoreline. Depositional and erosion patterns of soil, plant community control the edaphic characteristics which incorporate organic matter, nutrients and modify soil salinity and redox conditions [43]. In this estuarine system, the amount of SIC mainly depends upon temperature of soil, its redox condition, and microbial activity [10, 31]. In the present study it is also seen that temperature and $\mathrm{pH}$ also have influence on organic and inorganic carbon pool of the soil. In the absence of physiological stress by sulphide and salinity, soil nutrient availability is considered as the key factor for determining mangrove biomass and productivity [28]. It is observed that $R_{p}$ attains its lower value during monsoon $(+68.5 \mathrm{mV}$ to $+106 \mathrm{mV})$, whereas the higher values are observed during premonsoon $(+140 \mathrm{mV}$ to $+160 \mathrm{mV})$ and postmonsoon shows moderate values. The measure of electron pressure or its availability in a solution is called redox potential. Degree of electrochemical reduction of soil is often quantified by measuring redox potential [44]. Due to inundation in the monsoon months anaerobic conditions in soil exist. Pore spaces in the soil are filled with water and rate of oxygen diffusion is reduced enormously. Lower values of $R_{p}$ in monsoon are caused for heavy rainfall during this period, which results in water logging, as the clay particles are predominant in this area in comparison to silt particles. However during premonsoon, higher air temperature enhances the diffusion of oxygen in soil which in turn increases the redox potential. Oxidation of soil is very common at the depth of $8-10$ inches $(20-25 \mathrm{~cm}$ approximately) of mangrove forest bed. For SIC estimation, soil samples are collected from this depth.

During postmonsoon temperature remains low. Mangroves litterfall is increased at that time; also microbial activity is lowered. That is the reason SOC values remain high during this period. Dissolved oxygen content is high in winter months. As the temperature remains high in summer, diffusion at the air-water interface occurs at high rate and community metabolism also remains at high level. Thus dissolved oxygen content of water becomes low at that time of the year.

\section{Conclusion}

Mangrove litter and soil temperature are very important for soil system whereas the controlling factors for water system are salinity, $\mathrm{pH}$, and dissolved oxygen. This can be further illustrated in the aspect of spatiotemporal modelling to understand the dynamics of nutrient with abiotic factors which in turn controls sustainability of the system. Plankton dynamics can also be integrated to extend this study for better understanding of the system.

\section{Conflict of Interests}

The authors have no conflict of interests whatsoever.

\section{Acknowledgments}

One of the authors (Joyita Mukherjee) is thankful to University Grants Commission (UGC), Government of India, New Delhi, for providing RFSMS fellowship as financial support to carry out this work and Institute of Environmental Studies and Wetland Management (IESWM), Salt Lake, Kolkata, and West Bengal Pollution Control Board for giving the opportunity to carry out experiments on their laboratories. Joyita Mukherjee is also thankful to Mr. Jalad Gayen for his assistance in the collection of samples during field surveys for this work.

\section{References}

[1] P. P. Rakhecha and V. P. Singh, Applied Hydrometeorology, Springer, 2009.

[2] M. M. Sarin, S. Krishnaswami, J. R. Trivedi, and K. K. Sharma, "Major ion chemistry of the Ganga source waters: weathering in the high altitude Himalaya," Proceedings of the Indian Academy of Sciences-Earth and Planetary Sciences, vol. 101, no. 1, pp. 8998, 1992.

[3] T. K. De, S. K. Ghosh, T. K. Jana, and A. Choudhury, "Phytoplankton bloom in the Hooghly estuary," Indian Journal of Marine Sciences, vol. 20, no. 2, pp. 134-137, 1991.

[4] T. K. De, S. K. Ghosh, T. K. Jana, and A. Choudhoury, "Control of Primary productivity by suspended particulate matter in the Hugli estuary," India Tropical Ecology, vol. 31, pp. 98-103, 1990.

[5] S. K. Ghosh, T. K. De, A. Choudhoury, and T. K. Jana, "Oxygen deficiency in Hooghly estuary, East Coast of India," Indian Journal of Marine Sciences, vol. 20, pp. 216-217, 1991.

[6] S. K. Mukhopadhyay, H. Biswas, T. K. De, B. K. Sen, S. Sen, and T. K. Jana, "Impact of Sundarban mangrove biosphere on the carbon dioxide and methane mixing ratios at the NE Coast of Bay of Bengal, India," Atmospheric Environment, vol. 36, no. 4, pp. 629-638, 2002.

[7] H. Biswas, S. K. Mukhopadhyay, T. K. De, S. Sen, and T. K. Jana, "Biogenic controls on the air-water carbon dioxide exchange in the Sundarban mangrove environment, northeast coast of Bay of Bengal, India," Limnology and Oceanography, vol. 49, no. 1, pp. 95-101, 2004.

[8] P. B. Ghosh, B. N. Singh, C. Chakraborty, A. Saha, R. L. Das, and A. Choudhury, "Mangrove litter production in the tidal creek of Lothian island, Sunderbans, India," Indian Journal of Marine Sciences, vol. 19, pp. 292-293, 1990.

[9] S. K. Mukhopadhyay, H. Biswas, T. K. de, and T. K. Jana, "Fluxes of nutrients from the tropical river Hooghly at the land-ocean boundary of Sunderbans, NE Coast of Bay of Bengal. India," Journal of Marine Systems, vol. 62, no. 1-2, pp. 9-21, 2006.

[10] S. Mandal, S. Ray, and P. B. Ghosh, "Modelling of the contribution of dissolved inorganic nitrogen (DIN) from litterfall of adjacent mangrove forest to Hooghly-Matla estuary, India," Ecological Modelling, vol. 220, no. 21, pp. 2988-3000, 2009.

[11] H. Biswas, M. Dey, D. Ganguly, T. K. De, S. Ghosh, and T. K. Jana, "Comparative analysis of phytoplankton composition and abundance over a two-decade period at the land-ocean boundary of a tropical mangrove ecosystem," Estuaries and Coasts, vol. 33, no. 2, pp. 384-394, 2010.

[12] R. G. Wetzel, Limnology, Lake and River Ecosystems, Academic Press, San Diego, Calif, USA, 3rd edition, 2001. 
[13] S. Ray, "Comparative study of virgin and reclaimed islands of Sundarban mangrove ecosystem through network analysis," Ecological Modelling, vol. 215, no. 1-3, pp. 207-216, 2008.

[14] C. Giri, E. Ochieng, L. L. Tieszen et al., "Status and distribution of mangrove forests of the world using earth observation satellite data," Global Ecology and Biogeography, vol. 20, no. 1, pp. 154-159, 2011.

[15] K. Chakrabarti, "Sundarbans Mangroves of India-a study on conservation status," Indian Forester, vol. 113, no. 5, pp. 352-358, 1987.

[16] D. Ganguly, A. Mukhopadhyay, R. K. Pandey, and D. Mitra, "Geomorphological study of Sundarban Deltaic Estuary," Journal of the Indian Society of Remote Sensing, vol. 34, no. 4, pp. 431-435, 2006.

[17] S. Ray and M. Straškraba, "The impact of detritivorous fishes on a mangrove estuarine system," Ecological Modelling, vol. 140, no. 3, pp. 207-218, 2001.

[18] S. Saha and A. Choudhury, "Vegetation analysis of restored and natural mangrove forest in Sagar Island, Sundarbans, East Coast of India," Indian Journal of Marine Sciences, vol. 24, pp. 133-136, 1995.

[19] A. Walkley and I. A. Black, "An examination of the Degtjareff method for determining soil organic matter, and a proposed modification of the chromic acid titration method," Soil Science, vol. 37, no. 1, pp. 29-38, 1934.

[20] P. K. Gupta, Methods in Environmental Analysis: Water, Soil and Air, Agrobios, Jodhpur, India, 2000.

[21] G. N. Chattopadhyay, Chemical Analysis of Fish Pond Soil and Water, Daya Publishing House, New Delhi, India, 1998.

[22] APHAA, Standard Methods for the Examination of Water and Wastewater, 18th edition, 1992.

[23] J. Leps, M. Straskaba, B. Desortova, and L. Prochaszkova, "Annual cycles of plankton species composition and physical chemical conditions in Slapy Reservoir detected by multivariate analysis," Archiv für Hydrobiologie, vol. 33, pp. 934-945, 1990.

[24] P. Legendre and L. Legendre, Numerical Ecology, Elsevier, 2nd edition, 2003.

[25] R. B. Tomlinson, The Botany of Mangroves, Cambridge University Press, Cambridge, UK, 1986.

[26] W. E. Odum, C. C. McIvor, and T. J. Smith, The Ecology of the Mangroves of South Florida: A Community Profile FWS/OBS81/24, United States Fish and Wildlife Service/Office of Biological Services, Washington, DC, USA, 1982.

[27] C. C. Mclvor, J. J. Ley, and R. D. Bjork, "Changes in fresh water inflow from the Everglades to Florida Bay including effects on biota and biotic processes: a review," in Everglades: The Ecosystem and Its Restoration, S. M. Davis and J. C. Ogden, Eds., pp. 117-146, St Lucie Press, Delray Beach, Fla, USA, 1994.

[28] R. Chen and R. R. Twilley, "Patterns of mangrove forest structure and soil nutrient dynamics along the Shark River estuary, Florida," Estuaries, vol. 22, no. 4, pp. 955-970, 1999.

[29] W.-J. Cai and Y. Wang, "The chemistry, fluxes, and sources of carbon dioxide in the estuarine waters of the Satilla and Altamaha Rivers, Georgia," Limnology and Oceanography, vol. 43, no. 4, pp. 657-668, 1998.

[30] I. T. Jolliffe, Principal Component Analysis, Springer, 2nd edition, 2002.

[31] J. Mukherjee, S. Ray, and P. B. Ghosh, "A system dynamic modeling of carbon cycle from mangrove litter to the adjacent Hooghly estuary, India," Ecological Modelling, vol. 252, pp. 185195, 2013.
[32] K. G. Boto and J. T. Wellington, "Soil characteristics and nutrient status in a Northern Australian mangrove forest," Estuaries, vol. 7, no. 1, pp. 61-69, 1984.

[33] I. C. Feller, "Effects of nutrient enrichment on growth and herbivory of dwarf red mangrove (Rhizophora mangle)," Ecological Monographs, vol. 65, no. 4, pp. 477-505, 1995.

[34] G. Cintron, A. E. Lugo, D. G. Pool, and G. Moris, "Mangroves of arid environment in Puerto Rico and adjacent islands," Biotropica, vol. 10, pp. 110-121, 1978.

[35] A. E. Lugo, "Stress and ecosystems," in Proceedings of the Energy and Environmental Stress in Aquatic Systems, pp. 62-101, Augusta, Ga, USA, November 1977.

[36] N. H. Nickerson and F. R. Thibodeau, "Association between pore water sulfide concentrations and the distribution of mangroves," Biogeochemistry, vol. 1, no. 2, pp. 183-192, 1985.

[37] K. L. McKee, I. A. Mendelssohn, and M. W. Hester, "Reexamination of pore water sulfide concentrations and redox potentials near the aerial roots of Rhizophora mangle and Avicennia germinans," American Journal of Botany, vol. 75, no. 9, pp. 13521359, 1988.

[38] K. L. McKee, "Soil physicochemical patterns and mangrove species distribution-reciprocal effects?" Journal of Ecology, vol. 81, no. 3, pp. 477-487, 1993.

[39] V. J. Chapman, Mangrove Vegetation, J. Cramer, Vaduz, Germany, 1976.

[40] G. E. Walsh, "Mangroves: a review," in Ecology of Halophytes, R. Reimold and W. Queen, Eds., pp. 51-174, Academic Press, New York, NY, USA, 1974.

[41] K. Park, C. L. Osterberg, and W. O. Forster, "Chemical budget of the Columbia River," in The Columbia River Estuary and Adjacent Ocean Waters, A. T. Pruter and D. L. Alverson, Eds., pp. 123-134, University of Washington Press, Seattle, Wash, USA, 1972.

[42] J. H. Carpenter, W. L. Bradford, and V. Grant, "Processes affecting the composition of estuarine waters," in Estuarine Research, L. E. Cronin, Ed., vol. 1, pp. 188-214, Academic Press, 1975.

[43] I. B. Thom, "Magrove ecology and deltaic morphology: Tabasco, Mexico," Journal of Ecology, vol. 55, pp. 301-343, 1967.

[44] W. J. Mitsch and J. G. Gosselink, Wetlands, Van Nostrand Reinhold Company, New York, NY, USA, 1986. 

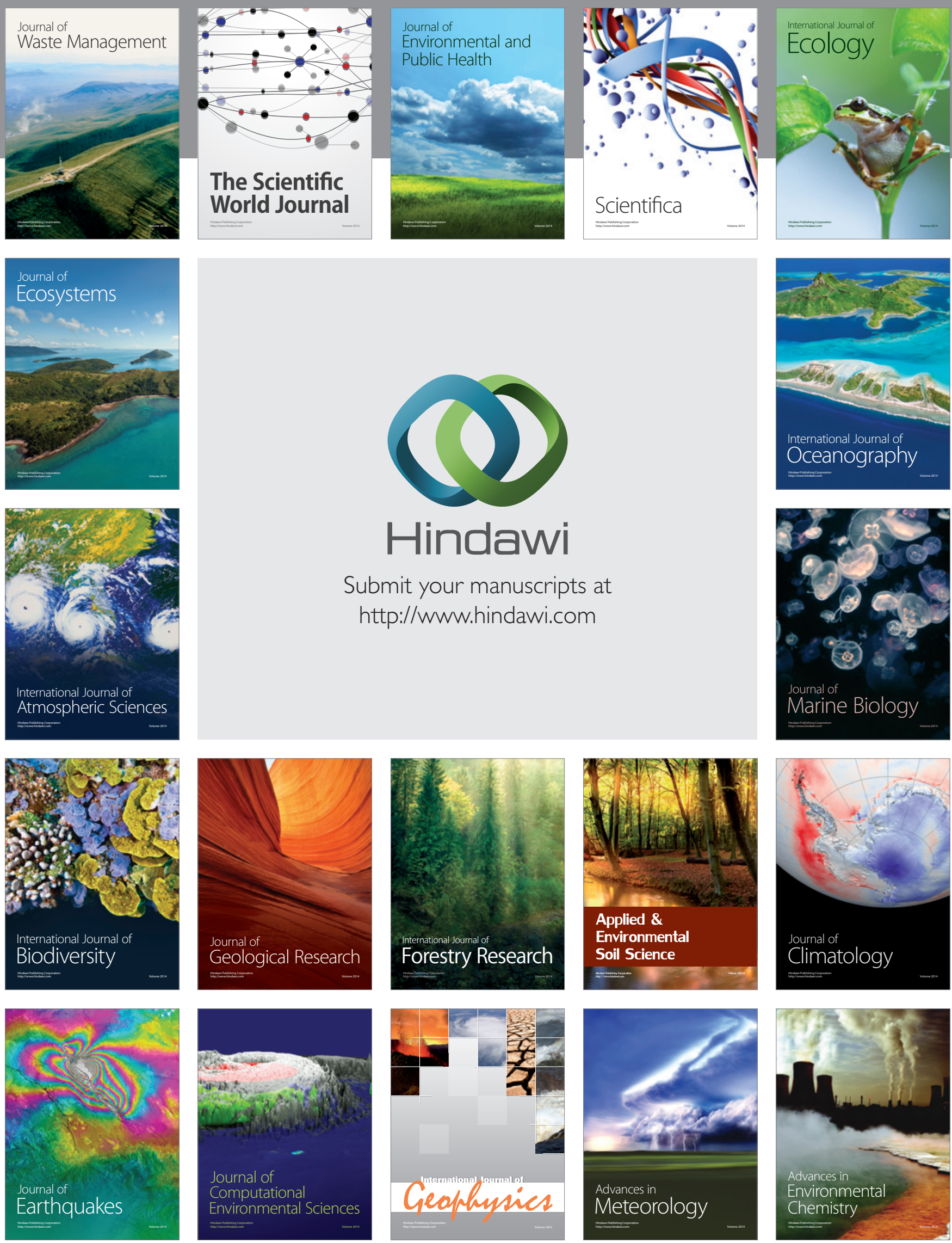